\title{
(Re-)constructing Nuclear Waste Management in Sweden: The Involvement of Concerned Groups, 1970-2010
}

\author{
Jonas Anshelm and Vasilis Galis \\ The Department of Thematic Studies, Linköping University \\ Sweden
}

\section{Introduction}

Since the mid 1970s, the Swedish government has exerted considerable pressure on the nuclear power industry to develop a method for the final storage of spent nuclear fuel. In 2009, after almost thirty-five years of intensive research, large investments, and heated conflict with the anti-nuclear movement, SKB - a company launched by the Swedish nuclear energy industry to manage nuclear wastes - submitted a proposal for disposing of highlevel nuclear waste in Sweden. This development has attracted considerable international attention. For example, the European Commission integrated the Swedish solution into its plans to develop a new sustainable nuclear energy technology platform for Europe (Elam and Sundqvist, 2009), making Sweden a frontrunner in nuclear waste management research. The advanced technological method proposed by SKB, referred to as the KBS-3 concept, involved high-level nuclear waste being contained in copper canisters, surrounded by benthonic clay, and put in a final storage repository at a depth of 500 meters in solid bedrock. According to SKB's proposal, the repository should be located in the municipality of Östhammar, near the Forsmark power plant, on the east coast of Sweden. In years to come, the Swedish government is expected to decide whether or not the KBS-3 concept meets its standards for safe disposal.

If KBS-3 is proclaimed safe and reliable, this will automatically be of great interest for countries using nuclear energy around the world. The Swedish solution is generally acknowledged as one of the most ambitious, technologically advanced, and carefully prepared projects for final storage, putting Sweden in the vanguard of nuclear waste management (Anshelm, 2006, p. 78, pp. 115, 163; Kantara, 2007). This estimation is supported by the British government's recent adoption of KBS-3 as a reference repository concept for disposing of spent nuclear fuel (Elam and Sundqvist, 2009). Accordingly, successful implementation of KBS-3 in Sweden may facilitate the expansion of nuclear power, at least in Europe. How is it possible that a small country such as Sweden has become a frontrunner in this endeavor? A preliminary explanation could refer to Swedish political culture, to its characteristic consensus and cooperation, and to the strategic actions of the nuclear energy industry, politicians, and authorities (Sundqvist, 2002; Lidskog and Sundqvist, 2004; Elam and Sundqvist, 2007). However, for almost five decades, the issue of nuclear waste management in Sweden has been permeated with profound public 
controversy between the nuclear power industry and various concerned groups (cf. Callon, 2003). In several major nuclear powers, such as the USA, the UK, and France, multiple social groups have also become involved in making nuclear waste storage a social and political problem (see, e.g., Rydel, 1984; Kronick, 1984; Chilvers, 2005, p. 242; Callon et al., 2009, p. 25). What has been the case in Sweden? Answering this question calls for multifarious inquiry to detect how concerned groups have coalesced around KBS-3, how they have influenced its development, as well as how they are influenced by being involved in a technoscientific controversy.

Accordingly, this article's aim is twofold: a. to empirically examine the technopolitics (we will come back to this notion) of the contemporary demos, including the influence exerted by concerned groups and their research efforts; and b. to analyze the transitions and social/epistemic identity-making that concerned groups undergo in order to maintain and increase their influence while seeking to (re)construct solutions to technoscientific problems. Technoscientific controversies imply a conflict of identities that is played out through conflicts over various kinds of knowledge, since it is impossible to distinguish the production of knowledge from the production of social identities (Callon et al., 2009, p. 105). Thus, we are interested in analyzing how concerned groups shape technopolitics and in how technopolitics shapes concerned groups. Whereas science and technology studies (STS) has previously been preoccupied with the former issue, one of our intentions is to demonstrate the usefulness of dealing with the latter. Our empirical investigation aims to enrich and broaden conceptual inquiry into how the "political" is implicated in the "technoscientific" (and vice versa) and into the role, epistemic identity, and scientific/research capacity of concerned groups.

To further our investigation, we will employ concepts and theoretical arguments emerging from STS. In the past three decades, STS has accentuated the congruence between technoscience and politics (what we call technopolitics), partly by challenging the expert authority of powerful scientific, state, and economic institutions and partly by articulating and representing lay, non-hegemonic epistemic views, engaging with science and technology via environmentalism, anti-globalization, consumer boycotts, patient movements, and the like (Jasanoff, 2004, p. 91). Through the conceptual lens of STS and given our focus on the historic endeavors of groups concerned with nuclear power and spent nuclear fuel storage, we will attempt to tell the story of the technopolitics of KBS-3.

\section{Conceptual discussion: From politically legitimate deconstruction to scientific legitimate reconstruction}

The nuclear waste management controversy in Sweden, as introduced above, resembles what Jasanoff (1992) calls a "quadrille dance": a historic movement performed by actors shifting between epistemological positions. STS has a long tradition of empirically dealing with controversies regarding the politics of technoscience, that is, who can legitimately make and control crucial policy decisions concerning science and technology. The latter immediately raises new questions: should science and technology be identified with politics or should they be preserved from the "prattle" of the public? Are technoscience and politics incompatible or inseparable notions? For Callon et al. (2009), it would be tragic to separate politics from technoscience, since they nourish each other. Social analysis ought to avoid fabricating identities such as the powerful and objective scientist while consigning laypeople to the level of emotion and passion: science and passion, knowledge and social roles are 
inseparable and co-constructed (p. 106). This is not to say that science and technology can be reduced to mere politics. In line with Barry (2001), we do not mean to denounce or condemn technology by asserting that it can be political; on the contrary, we also believe that controversies over technoscience open up new objects and sites of politics (p. 9).

Despite their efforts to radically redefine the concept, STS scholars seem to have made the same mistake regarding the concept of "politics" as they accused earlier social scientists of making regarding the concepts of "science" and "technology." They have partly to entirely entrenched politics within a general and abstract citadel of "decision-making," either in the "public domain" or exercised by the official machinery of the government, and partly used the same kind of modernist rhetoric that separates scientists from politicians, science/technology from politics, and experts from laypeople (de Vries, 2007). Indeed, Latour (2007) recognizes that STS has been preoccupied with focusing the analysis on deconstructing technoscientific practice, making the adjective "political" a meaningless concept: everything is political, but it is not explained how (p. 812-813). Identifying science and technology with politics without discussing how these domains intersect gave rise to a double criticism of STS articulated, on one hand, by those skeptical of the politicization of science and technology and, on the other hand, by activist social researchers who were worried about shining analytical light on areas unrelated to traditional political action. This makes for a tricky balance, and STS researchers have sometimes debated for and against both kinds of "deviations."1 One way to go about this is to mix the public with technoscience, but reshaping the concept of "politics" this time. Yes, science and technology are "politics by other means," but what exactly does "by other means" mean? In the same paper, Latour offers five new meanings/interpretations of the word "political," situating them in five domains of technopolitical practice:

\begin{tabular}{|l|l|}
\hline Meanings of "political" & What is at stake in each meaning \\
\hline Political-1 & New associations and cosmograms \\
\hline Political-2 & The public and its problems \\
\hline Political-3 & Sovereignty \\
\hline Political-4 & Deliberative assemblies \\
\hline Political-5 & Governmentality \\
\hline
\end{tabular}

Source: Latour (2007), p. 818

Table 1. Five meanings of "political"

In the first meaning, political-1, Latour argues that every non-human entity interacting with humans helps (re)configure the sociotechnical order. In our case, spent nuclear fuel, soil, water, etc., demanded redefinition of the discussion of nuclear power and nuclear waste management by scientists. When the redefined issue of nuclear waste management generated a concerned public, then it became political-2. To resolve the concerns of social groups, governments often attempt to turn a problem into a clearly articulated question of

\footnotetext{
1 See, for example, the debate, organized by Evelleen Richards and Malcolm Ashmore, "More sauce please! The politics of SSK: neutrality, commitment, and beyond," in Social Studies of Science 26(2), pp. 219-228, May 1996; see also, for example, Collins and Evans (2002) and Woodhouse et al. (2002).
} 
common good. For example, in the 1950s and 1960s, the state-owned Swedish nuclear power industry insisted that, unlike other industries, they paid serious attention to questions of industrial waste in the planning phase, which guaranteed that there was no reason to worry (Anshelm and Galis, 2009, p. 273). However, when the machinery of government fails to cope with public concerns, as was the case with nuclear waste in Sweden at an early stage, then the issue becomes political-3. The questioning of both expert knowledge and governmental authority to resolve a (previously) strictly technoscientific issue creates the opportunity for deliberative procedures (political-4). This is when concerned groups begin to claim the right to participate in the configuration of policy-making, for example, as various lay groups did in the anti-nuclear movement, and when concerned scientists entered the Swedish debate on nuclear waste in the early 1970s. This is when radioactive waste becomes "socio-active" (cf. Callon et al., 2009, p. 109). Finally, Latour defines political5 as the "repoliticization" of all technoscientific issues that have become daily apolitical routines and rigid parts of the sociotechnical stratum. As mentioned, the renaissance of nuclear power called for repoliticizing the issue of nuclear waste management.

We should mention here that a technoscientific issue can be political in all five senses at the same time, the sense emphasized depending on where the analytical weight and epistemological focus lies. The aforementioned definitions do not constitute chronological phases that historically succeed each other, but rather overlapping aspects or layers of a single issue, in this case, nuclear waste management. Now that we have established a conceptual basis for the congruence of technoscience and politics to help us examine the technopolitical nature of nuclear waste management, let us define the ontological and epistemological margins of this study; in other words, at what loci and how will this paper address technopolitical action?

To answer the first part of the question, the empirical examination begins by briefly reviewing the configuration of nuclear waste management in Sweden from the 1950s to 1970s (political-1 and -2), continues by thoroughly analyzing the deliberative involvement of the environmental and anti-nuclear movements in areas previously dominated by scientific experts (political-3 and -4), and concludes by adding another meaning to Latour's interpretive schema of the word "political." As we will demonstrate, the development of the nuclear waste management issue never became "part of the daily routine of administration and management," since it was actively and closely monitored by a group of concerned activists, journalists, academics, and citizens. This group progressively advanced its engagement from merely participating in deliberative processes to constructing sophisticated scientific proposals and participating equally in the technoscientific debate. This circular epistemic identity-shifting, what we previously called the sociotechnical quadrille, is characterized as political-6 according to our schema.

The ontological exercise of this paper is to identify and discuss the quadrille steps involved in the nuclear waste management issue, which range from political-1 to political-6 (possibly bypassing political-5). In doing this, we will employ the main methodological approach that Latour's STS version has propagated since the mid 1980s, namely, following the actors "both as they attempt to transform society and as they seek to build scientific knowledge or technological systems" (Callon, 1986). In other words, we seek to analyze technopolitical action as taken by concerned groups within the complexity of a sociotechnical issue/controversy. As Latour (2007, p. 814) acknowledges, without an issue there is no politics. How do we identify and trace an issue? In our case, and answering the question on epistemology, to follow the actors and trace the issue, one must delve into the historical 
backgrounds of the environmental and anti-nuclear movements in Sweden. The 1970s were marked by general attacks on science, the political system, modernity, and the mainstream approach to nuclear power, contributing to what Foucault (2003) termed "the insurrection of subjugated knowledges." This sort of autonomous and decentralized knowledge, previously disqualified as non-conceptual, insufficient, and hierarchically inferior by the gatekeepers of "scientificity," appeared from below, based on what people knew and experienced at a local level (pp. 5-10). The insurrection of subjugated knowledges establishes the basis for the construction of knowledge outside the secluded laboratory and policy room, making nuclear waste management a political-4 issue.

Nevertheless, the model of activist and academic critical deconstruction of scientific "facts" and artifacts that accentuated the "lack of scientific certainty" has also begun to face critical scrutiny. As Latour (2004) argues, the issue was never to abandon the construction of facts or to reject dogmatically the production of technoscientific knowledge, but to come closer to them and renew empiricism by adding reality to established matters of fact (pp. 231-232). In doing so, the close study of technopolitical complexity in knowledge production also includes answering questions regarding who counts as a legitimate participant in a technoscientific dispute and who makes decisions concerning issues of participation (e.g., a substate organ, the nation state, a suprastate organization, the scientific community, or the claimants of citizenship) (cf. Jasanoff, 2004, p. 92). This line of argumentation is valuable in two ways, epistemological and ontological. On one hand, it marks a conscious effort by the social sciences and STS to go beyond the label of "deconstruction" by embarking on epistemological inquiry that allows interventionist modes of more socially grounded accounts of science and collaborative research and by promoting collective deliberation and co-construction (or co-production) of science and society, or even reconstruction of technoscience, in a manner that may be productive for both scientific scholars and activists (Jasanoff, 2004, pp. 68-69; see also Woodhouse et al., 2002; Mesman, 2007). On the other hand, it allows concerned groups that have been earlier neglected by confined scientific communities (Callon et al. 2009, p. 46) to reclaim their position not only in social analysis but also in the technopolitical agora as legitimate carriers of technoscientific knowledge (political-4).

In the words of Callon et al. (2009), the research collective cannot be identified with a simple group of researchers, but constitutes a community of distributed intelligence (p. 57), a community of distributed epistemic capacity. The "concerned groups" concept describes a dynamic process in which groups concerned with technoscience not only assert their existence, enact their identity, and formulate their demands, but also transform their epistemic status by actively participating in technopolitics. Accordingly, we are interested in how the epistemic status/identity of laypeople (e.g., activists, journalists, academics, and citizens-all concerned groups) is distributed, depending on their negotiability and participation (or lack thereof) in configuring various technopolitical practices. In this study, the anti-nuclear movement and its advocates will be treated as a concerned group in transition. In line with Callon (2003), a theoretical focus on the participation of laypeople and on the transformations of their epistemic identity implies a shift from traditional decision-making models: lay involvement delivers a preliminary blow to the traditional division between scientists and laypeople (p. 57).

This is the process that Callon describes as "research in the wild," whereby laypeople take action and participate in producing scientific facts ("the insurrection of subjugated knowledges"). To achieve this participation, laypeople establish new practices, exploit 
existing knowledge, negotiate with other groups, and form new organizational configurations (Galis, 2006, p. 40). Callon and Rabeharisoa (2003, p. 62) define "research in the wild" as the process by which laypeople accumulate and compare their experience and build collective expertise as authentic as that of "experts or scientists," even though it is different. In contrast to confined research, research in the wild does not possess or claim "scientific" purity; instead, it directly confronts compound, impure, polluted realities. The concept of research in the wild highlights the perspective that the management of technoscientific facts and artifacts does not have to follow the traditional laboratory route, which often implies a relatively passive role for the public sphere and the domination of scientists and engineers (Galis, 2006, p. 40). After all, laypeople possess expertise concerning their own needs, which is crucial knowledge when it comes to designing and implementing various technologies and which emerges from research in the wild. This conceptual apparatus allows us to "trace the issue" and follow the (de/co/re)construction of nuclear waste management by concerned groups and their research in the wild in Sweden since the 1950s.

\section{A note on method}

This paper analyzes the technopolitics of nuclear waste management in the public debate/controversy involving the nuclear industry and the anti-nuclear energy movement in Sweden. We are interested in the part of the debate articulated in printed documents. We agree with Ockwell and Rydin (2006) that controversies involving various knowledge holders can be understood fully by investigating the discursive bases of the various linkages between these parties (p. 381). Such a methodological choice lets us monitor the argumentation and rhetoric of the anti-nuclear movement, which has mainly employed the strategies of writing discussion pieces for publication in the mass media and scientific journals and of publishing books and leaflets to articulate their standpoints, instead of launching costly major campaigns. In this way, SKB was forced to confront the anti-nuclear movement in the formation of public opinion and to participate openly in media debate concerning nuclear waste management. The conflict/controversy has thus mainly been articulated in the public debate.

Accordingly, our analysis will be based on a close reading of articles in newspapers, websites, and scientific journals and of official reports, leaflets, and books. This material, which comprises over 1200 documents, was collected through extensive searches of databases (i.e., Artikelsök, Presstext, Mediaarkivet, and Biblioteksstjänsts tidnings- and tidskriftsindex) covering all Swedish newspapers and the most important Swedish journals. Books and official reports published in the study period were also examined. We also collected and analyzed articles and reports published on the websites of anti-nuclear organizations such as MKG and MILKAS. Our method entailed the close reading of every text situated in the debate in order to identify central meanings and themes. Individual texts were analyzed using a thematic coding technique for detecting patterns in qualitative data. This approach to coding was inspired by the analytical procedures developed by Strauss and Corbin (1990), but does not claim to be a grounded theory approach; instead, this study uses grounded theory methods as ways of categorizing and identifying patterns. Specific questions stood out as central, while others were found to be peripheral or even absent. Since the texts were produced over five decades, it was possible to detect shifts in arguments over time. More extensive empirical evidence than can be provided here to 
support certain interpretations can be found in the book Bergsäkert eller våghalsigt? (Anshelm, 2006).

\section{The issue of nuclear waste management in Sweden: from confined research to technopolitics}

\subsection{The nuclear power industry and the declared absence of risk}

In the 1950s and 1960s, the issue of nuclear waste in Sweden was the sole purview of scientific or state authorities. It was generally understood that the Swedish nuclear industry, comprising Atomenergi $\mathrm{AB}$ (Atomic Energy Ltd.), and state authorities shared the responsibility for nuclear waste management. When the issue was raised, nuclear physicists, reactor engineers, and politicians maintained that future technology would eliminate any waste-handling problems. Information leaflets from the nuclear energy industry did not even mention risks related to nuclear waste. In newspaper articles, nuclear physicists and reactor engineers predicted that people in the future would learn to live with and handle radiation, just as they had learned to live with and handle electricity (Westermark, 1952; Brynielsson and Eklund, 1954; Svedberg, 1955a; Funke, 1956; AB Atomenergi, 1957). In the same period, in Europe as in Sweden, communication specialists explained, popularized, and reassured: there really was no risk (Callon et al., 2009, p. 14; Anshelm, 2006, p. 34). At the time, it was very unusual to question the statements of confined research concerning nuclear waste and its management, even though these statements were sometimes only speculations concerning future technology. In that period, both scientific and political lobbies perceived nuclear waste as essentially a risk-free scientific issue (Anshelm, 2006, p. 28). Laypeople still constituted outsiders who were unable to influence the scientific/political configurations of nuclear waste.

\subsection{The rise of the anti-nuclear movement and the entrance of laypeople into the debate}

In the early 1970s, the first conflict emerged concerning the social and environmental characteristics of risks associated with nuclear waste. Plans to open a reprocessing facility in Bohuslän in western Sweden drew protests. A local environmental movement was mobilized to prevent the building of what they called a "plutonium factory." It was argued that the facility would expose the local inhabitants to great risks and that plutonium produced during reprocessing was one of the most dangerous and long-lived poisons known (Jacobsson, 1969; Johansson, 1969). At the same time, scientists such as Hannes Alfvén ${ }^{2}$ and Sten Lindeberg began to criticize the scientific reasoning of the authorities responsible for future nuclear waste management as well as the science underlying the first official report on nuclear waste. The aforementioned physicists made clear in public debate that the scientific statements underpinning the political decisionmaking were nothing but qualified interpretations molded by political, economic, and

\footnotetext{
${ }_{2}^{2}$ Alfvén, a physicist awarded the Nobel Prize, was engaged early on as an expert in planning the Swedish nuclear energy program and later became familiar with the nuclear energy debate in the USA. He wrote an open letter to the Swedish government pointing out that nuclear energy and especially nuclear waste involved enormous risks; he also warned that the mass production of nuclear waste could eventually poison the earth and jeopardize the future of humanity (Alfvén, 1972).
} 
technological interests. Science was not politically neutral, and it was possible to formulate alternate scientific interpretations that were as trustworthy as the established ones (Blomfeldt, 1976; Lindeberg, 1976).

Following the Bohuslän events, in spring 1970, a lengthy debate concerning the risks related to nuclear waste was initiated in the pages of Dagens Nyheter, the leading Swedish daily newspaper. On one side were spokespeople for what some years later became the anti-nuclear movement, while on the other stood representatives of the authorities responsible for radiation and of the nuclear energy industry. Suddenly, nuclear waste, which reactor engineers and radiation experts still insisted was not a problem, had become the subject of public controversy (Gillberg, 1970; Lindell, 1970; Jugnell, 1970). The intense discussion led to nuclear waste management being seen as the most urgent environmental issue facing Sweden in 1972. Criticism that the risks had been neglected for years grew as the anti-nuclear movement increased its influence (Anshelm, 2006, pp. 39-41). In 1973, the Swedish parliament imposed a moratorium on commissioning new nuclear power plants until a reliable plan for nuclear waste management had been presented (Lindquist, 1997). In fewer than four years there had been considerable reconfiguration of public discussion of the risks related to nuclear waste. The same period marked the entrance of laypeople, in the form of an anti-nuclear movement, into the debate on nuclear waste (Anshelm, 2006, pp. 37-66); confined research and its scientific authority were under attack. These were the very first critical voices that set the stage for the beginning of the quadrille.

Inspired by Alfvén, politicians in the Centre Party also began to question the scientific statements of researchers in the nuclear energy industry, winning a historic victory in the 1976 parliamentary election by emphasizing the overwhelming risks related to the storage of spent nuclear fuel (Rainer, 1973; Fälldin, 1976). After 44 years in office, the social democrats were thrown out when the Centre Party joined forces with the anti-nuclear movement and researchers in the wild, aligned against the nuclear power industry and state authorities. The first steps in the sociotechnical quadrille, taken when Prime Minister Thorbjörn Fälldin was elected based on the epistemic status of concerned groups and oppositional activistscientists, had severe consequences for Swedish energy politics for decades to come (Anshelm, 2000, pp. 111-193).

\subsection{Researchers in the wild go deconstructivist}

The anti-nuclear movement and environmental organizations engaged their own scientific experts to conduct research in the wild, to deconstruct the scientific statements and truth claims articulated in state investigations and industry reports. This marked a turning point in the debate, since it was the first time that nuclear waste management was referred to as a hazard to the public (Anshelm and Galis, 2009, p. 273). At the same time, it was obvious that the nuclear waste issue no longer constituted an object of purely scientific concern, defined solely by participants in confined research. On the contrary, a social movement expressed its distress and questioned scientific and state authority regarding nuclear waste management, making it a political-2 issue. The hegemony of confined research was being seriously deconstructed. Researchers in the wild-i.e., oppositional scientists, journalists, environmentalists, politicians, and concerned laypeople-questioned "facts" pronounced in the name of science by confined scientists, because they interpreted these "facts" as expressions of political interests/concerns and thought that they exceeded what could be confirmed from a strictly scientific viewpoint (Lindeberg, 1976; Moberg, 1976; Westman, 
1976). It was no longer possible to talk about nuclear waste management without at the same time saying something about what constituted a desirable society. The first steps in the quadrille had been taken.

In 1976, the first state investigation of nuclear waste management was presented (SOU, 1976). ${ }^{3}$ What is important about this investigation was its insistence on conducting a completely new risk evaluation and on finding convincing methods for securing final storage. Risks related to nuclear waste were no longer peripheral unquestionable scientific facts to be left to confined research-that is, scientists and engineers working on the assumption that people would learn to live with the risks. Instead, presenting a reliable storage method in advance became a prerequisite for the further development of nuclear energy in Sweden. Accordingly, the nuclear industry and reactor engineers had to change their risk evaluations as well and thereby their position in the dance. For the first time, the anti-nuclear movement did not simply oppose confined research and nuclear industry, but made concrete suggestions concerning safe storage methods. In that sense, laypeople no longer constituted just a skeptical activist group, but now sought to "stick their noses" into technoscience. It was truly an insurrection of subjugated knowledges against unreliable storage methods.

Ultimately, the nuclear energy industry yielded to the pressure of the anti-nuclear movement and its advocates, though this was certainly no unconditional capitulation. The first traces of research in the wild convinced the government to force the industry to embark on an ambitious research project to develop secure methods for managing and storing nuclear waste. A special company, SKB, owned by the nuclear energy industry, was created for this purpose. Through SKB, the nuclear energy industry took full responsibility for its byproducts and made large investments in research and technological development. Three suggestions for the final storage of nuclear waste were presented in proposals that became known as KBS-1-3, which focused on geological and technical aspects of storage. The proposals for final storage presented in the official report of the first state investigation had been developed and refined by a cadre of contracted experts (Rosenberg, 1977; Thunell et al., 1977; Mosesson, 1977). New proposals were circulated for comment nationally and internationally. SKB eventually presented a method for final storage of nuclear waste that was described as one of the most advanced in the world. The company insisted that this method would ensure secure storage of nuclear waste (Bjurström, 1986; Bjurström, 1988; Falk, 1995; Papp, 1995).

However, detailed examination of the various alternatives, as well as the considerable funds and research energy invested in the project, indicate that, in the 1970s and 1980s, decisionmakers in the nuclear energy industry defined risks differently from how their predecessors had. The risks posed by nuclear waste were taken much more seriously than before. Accordingly, the conflict between the nuclear energy industry and the anti-nuclear movement no longer concerned whether or not nuclear waste involved large risks. The conflict now concentrated on whether these risks could be handled using methods

\footnotetext{
${ }^{3}$ The so-called AKA investigation began on 25 April 1973, just one month before the moratorium was imposed. In this investigation-in which representatives of confined research (e.g., nuclear physicists and radiation experts), representatives of the nuclear energy industry, and politicians with an optimistic view of nuclear energy played important roles-risks related to nuclear waste were discussed more seriously than ever before in Sweden.
} 
developed solely by the nuclear energy industry, or whether researchers in the wild could deliver serious criticism and discuss alternatives. In answering that question, the nuclear energy industry, government, and the anti-nuclear movement, together with their consulting geologists, engineers, and radiation experts, came to completely different conclusions (Lindeberg, 1976; Mörner, 1978; Bjurström, 1986, 1988). This constitutes the first concrete dispute between research in the wild and confined research during the controversy regarding the storage of nuclear waste management in Sweden, a dispute that involved deconstructing "objective" scientific facts regarding nuclear waste and the occurrence of impure technopolitics, that is, different perceptions and proposals regarding storage methods. In the words of Callon et al. (2009), disorder arises partly when confined research fails to deliver pacifying knowledge on which a socially reassuring political debate can be developed and partly when laypeople are allowed to participate in discussing experiments and their results (p. 120). In this case, researchers in the wild even managed to receive the support of the Swedish government, which put considerable pressure on SKB by passing a law requiring the presentation of a completely secure method for storing spent nuclear fuel before any new reactors, including those already built, would be permitted to start operating (Anshelm, 2000, pp. 190-193).

\subsection{Test drilling and the insurrection of local resistance}

In the 1980s, SKB began test drilling in Swedish bedrock in order to meet the requirements established by the Centre Party-led government. Environmental organizations and critics of KBS perceived the Swedish bedrock as "living" and changeable. They enlisted the support of several geologists who testified that the bedrock had undergone any number of transformations, especially during ice ages. Geologists revealed traces of earthquakes, faults, fissure formation, and altered subsoil water flows. It would clearly be impossible to predict the condition of bedrock for a period of 100,000 years, especially if the bedrock contained a nuclear waste repository that might affect the flows of both subsoil water and water in fissures. Accordingly, the anti-nuclear movement, Greenpeace, and several local resistance groups opposed all forms of underground storage of nuclear waste. They asserted that the concept of "getting rid of" nuclear waste by simply burying it rested on the same view of nature that had caused earlier environmental disasters. The critic's view of nature could not accept the construction of a facility intended to keep nuclear waste isolated from the biosphere for an almost incomprehensibly long period. They argued that dry deposit and storage at ground level were preferable, since the nuclear waste could then be kept under constant surveillance and its containment would not be dependent on the changeable and unpredictable natural environment (Anshelm and Galis, 2009). Several geologists publicly deconstructed the company's geological assessments and local resistance groups refused to accept test drilling in their municipalities (Noresson, 1985; Mörner, 1988; Alfvén, 1988; Edberg, 1988; Gahrton, 1988).

As a result, in several places, drilling was obstructed by laypeople (concerned local residents), who claimed responsibility for future generations and the environment. However, they interpreted and acted on this responsibility in a way that differed completely from SKB's. They did not act on their responsibility by seeking methods for storing nuclear waste, but by protecting their home districts from the radioactive contamination they feared could result from inappropriate and untested methods of underground storage. Accordingly, they completely opposed KBS-3 and all underground storage of nuclear waste. 
This interpretation of responsibility was based on research in the wild, which mobilized counter-experts who deconstructed the claims of geologists and engineers contracted to SKB (Noresson, 1985). By the end of the 1980s, this resistance forced SKB to realize that the company could not take sole responsibility for nuclear waste storage: it would have to change tack again and allow local residents to share responsibility by involving them and winning their consent to any project. Any attempts to force waste storage measures on people were doomed to failure since they led to serious conflicts (Arpi, 1990). Concerned groups had not only forced the nuclear waste industry to dance with them, but had even made it change positions.

\subsection{Deconstructing the confined KBS}

This was definitely not the last step in the quadrille. Enlisting researchers in the wild was becoming increasingly unavoidable as concerned laypeople grew in number, formed alliances (e.g., local residents with counter-experts), and increasingly made themselves heard (cf. Callon, 2003, p. 54). Their voices helped co-construct both the risks related to nuclear waste management and how responsibility for this issue was articulated and manifested in the debate. Nuclear waste management was no longer an issue that concerned only confined experts and politicians, but was the subject of contention between research in the wild and confined research, something that prompted new research efforts and criticism. This also marked a shift in the epistemic identity and technopolitical involvement of concerned groups as well as the democratization of an initially purely technoscientific issue. In the 1970s and 1980s, concerned groups in Sweden did not limit their activism to merely deconstructing SKB's project; they also attempted to co-construct the issue of responsibility for the management of spent radioactive fuel. This allowed them to take a position in the debate on nuclear waste storage by defining the key issue (i.e., determining and evaluating sustainable and environmental policy alternatives for managing radioactive waste) and by assessing, with the help of their advocates, environmental risks and impacts as well as acceptable methods (i.e., dry deposit and ground-level storage instead of bedrock drilling). Nevertheless, there was still much to be done to integrate concerned groups completely into the policy-making.

The democratization of the spent fuel issue allowed critics of nuclear energy to consider every scientific statement about the future management of nuclear waste as technopolitical. Awareness of scientific and technical weaknesses led to the co-construction of the terms of the debate and the emergence of new inquiries and critiques (cf. Callon et al., 2009, p. 15). KBS-3 and SKB's technical reports were thoroughly reviewed and heavily deconstructed in every detail. Every single report was scrutinized by scientific counter-experts (including researchers in the wild) who maintained that the nuclear energy industry was presenting energy policy in a scientific guise (Lindeberg, 1978; Anér, 1978). In scientific disciplines such as geology, intense controversy arose between researchers working for SKB and independent researchers: the latter feared that the former were allowing geology to be used for purposes that could undermine its trustworthiness. Some critical researchers were part of the anti-nuclear movement and publicly denounced their colleagues for participating in KBS research (Mörner, 1978; Nilsson, 1978; Mörner, 1979; Sundqvist, 2002, pp. 150-171). Geologists spoke out against geologists, hydrologists against hydrologists, physicists against physicists, and engineers against engineers. Though most researchers defended KBS and considered its proposals scientifically valid, the critical researchers and researchers in the 
wild received not only much public attention but also considerable support in the Swedish parliament. Their accusations that SKB's reports had been revised to suit company interests undermined efforts to demonstrate that there was widespread scientific consensus concerning KBS-3. As a result, SKB was repeatedly forced to "refine" the KBS-3 concept, to defend itself from the attacks of research in the wild (Anshelm, 2006; Sundqvist, 2002).

This distrust was hardly reduced when KBS-3 was circulated for scientific comment in 1984. The anti-nuclear movement and several environmental organizations maintained that feedback from critical scientists and institutions had been removed and that only positive opinions had been retained (Ringsberg, 1984; Eriksson et al., 1986; Noresson, 1986). Critical remarks from researchers in the wild were also ignored, reinforcing the conviction in the anti-nuclear and environmental movements that the nuclear energy industry was conducting unscientific research and that all further production of nuclear waste should be stopped immediately. The critical geological and technological experts taking sides with the environmental organizations questioned the assumptions on which SKB's construction of repositories and encasements were based, addressing such issues as hydrological conditions, fissures, stability, and corrosion (Eriksson et al., 1986; Åhäll, 1986; Holmstrand, 1987; Mörner, 1988; Holmstrand, 1990). SKB rejected these criticisms and pointed out that a massive body of international scientific expertise had declared that KBS-3 was secure (Bjurström, 1988). The opposing positions were thus rigidly fixed and accusations of unscientific behavior were reciprocal. During that period, the technopolitical setting of nuclear waste management implied hard deconstruction of the opposing party's scientific profile and competence.

\subsection{The nuclear power industry's efforts to redistribute responsibility}

As demonstrated earlier, SKB's position was that disposal in massive bedrock would guarantee the secure storage of nuclear waste. Searching for the most suitable bedrock had accordingly been a priority. However, in the late 1980s, SKB announced that it was possible to construct a final repository almost anywhere in Sweden and that the most important barrier preventing radiation from reaching the biosphere was not the bedrock but the copper encasement of the waste. According to SKB, the role of the bedrock was no longer to prevent radioactive waste reaching humans but to prevent humans reaching nuclear waste (Bjurström, 1989; Ahlström, 1989; SKB, 1992; Sundqvist, 2002, pp. 113-116). This assertion rendered moot the whole question of whether the bedrock was stable. The problem was no longer the sustainability of nature but the sustainability of technological construction. This reorientation enabled SKB to avoid awkward geological questions while allowing nuclear waste storage facilities to be located wherever the political will to cooperate existed. The same reorientation occurred in the USA in 2000, when encasement rather than geological conditions was declared the most important factor in safe nuclear waste storage (Macfarlane, 2003:793). All of a sudden, SKB's rhetoric was based on political argumentation, i.e., striving for cooperation with a municipality, rather than purely scientific facts, i.e., geology.

Following this line, in 1992, SKB invited local residents to a new turn in the dance. The company wrote to all 286 municipalities in Sweden asking whether they were interested in cooperating with investigations of local bedrock to find suitable sites for a final repository for high-level nuclear waste. The technocratic model having failed, this letter invited municipalities and citizens to share responsibility for managing nuclear waste, making the 
issue a matter of common good. During this information campaign, SKB also pledged that the municipality selected as a repository would be guaranteed a considerable number of jobs for many years to come. Once cooperation with two municipalities in northern Sweden, Malå and Storuman, had begun, SKB representatives argued that the responsibility for handling nuclear waste rested on the entire Swedish population. SKB accordingly began to enlist laypeople in their project. All municipalities that might have suitable sites for a final repository had a moral obligation to help solve the problem, since it was in the common interest to ensure that storage was as secure as possible (Thegerström, 1993). These arguments indicate that a considerable shift had taken place. First, SKB did not base its campaign to recruit Swedish communities simply on scientific facts, but employed technopolitical, moral, and economic arguments. Second, SKB no longer saw itself as having sole responsibility for the storage of nuclear waste and for choosing sites on scientific grounds: SKB attempted to redistribute responsibility. Confined research no longer claimed a monopoly over scientific research and policy making; instead, it appealed, with varying success, to people's sense of responsibility for the common good. Early in the twenty-first century, the company managed to persuade several municipalities to express willingness to share this responsibility (Elam and Sundqvist, 2007).

\subsection{Concerned groups turn to science}

Nevertheless, SKB's consensus-making efforts and attempt to include laypeople in the discharge of responsibility was met with suspicion and resistance. Laypeople and their advocates had learned to mistrust information provided by nuclear agencies, even when they seemed above suspicion technically and morally (cf. Callon et al., 2009, p. 14). In the anti-nuclear and the environmental movements, there was strong opposition to SKB's proposal for underground storage, KBS-3, and to how the company supported its views by presenting more-or-less tendentious and made-up scientific results as unquestionable facts. The company's information campaigns were characterized as distorted, biased, and dishonest (Åhäll, 1986; Holmstrand, 1987). The distribution of responsibility was also deemed defective, as the opponents did not think that responsibility should rest with a private company owned by the nuclear energy industry, which would inevitably base its actions on principles that differed completely from those required to address serious environmental problems. The anti-nuclear movement argued that the state should assume responsibility for nuclear waste as soon as possible, to enable public control of the process (Bildström, 1997). The government's response was to assert that it considered the distribution of responsibility to be appropriate and based on the sound principle that the producers of nuclear waste should take responsibility for managing it. Moreover, state authorities had input into the process and the government retained the right to approve or reject SKB's proposals for final storage. The government was satisfied that the process being followed was democratic (Larsson, 2000).

The issue of responsibility emphasized the divide between laypeople, politicians, and experts. The developing dynamics of the anti-nuclear movement, the Swedish government's approach, and the nuclear industry's methods together led to the conflict. While the government and the nuclear industry considered SKB's suggestions appropriate, laypeople representing the anti-nuclear movement opposed all forms of underground storage, while struggling to find an alternate disposal method. The final objectives of both parties were clear: on one hand, SKB and the authorities urged maintaining nuclear waste management as a political-3 issue (i.e., articulating the problem as an issue of common good by attracting 
the interest of several Swedish municipalities) and, on the other hand, laypeople were struggling to breach the citadel of biased confined research and to integrate their own technopolitical actions into the debate on radioactive waste (political-4). While the intentions remained the same, we cannot say the same about the epistemic status of the opposing parties. On the contrary, it became apparent that several steps of the sociotechnical quadrille had been taken, and SKB was now employing social methods while the concerned groups began basing their arguments on technoscientific evidence. Such a redistribution of epistemic identity produced an extraordinary result. Those (e.g., researchers in the wild and the anti-nuclear movement) who had earlier accused SKB of being undemocratic when it carried out geologically motivated test drillings to find the most suitable bedrock, now accused it of neglecting geological and hydrological factors and of being prepared to base its choice of final storage site on the amount of political opposition the site would attract. SKB's critics maintained that the new focus on political acceptance rather than geological conditions made the company untrustworthy and dangerous (Holmstrand, 1990; Avfallskedjan, 2001).

In the 1980s, when SKB had made great efforts to find the most suitable bedrock, critics in the anti-nuclear movement and local resistance groups had strongly opposed this on the basis that all underground storage of nuclear waste was unjustifiable for geological reasons. Now, however, organizations that had previously opposed underground storage raised questions of the quality of bedrock in relevant municipalities, discussed alternative sites on geological grounds, and accused SKB of neglecting geological and hydrological factors. In contrast to the 1980s, the anti-nuclear movement was discussing geological and hydrological criteria in a positive way. Instead of simply condemning all underground storage, it pointed out that the most suitable geological formations were in inland areas with slow subsoil water flow (Holmstrand et al., 2002). SKB and the anti-nuclear movement had now switched positions, but there was nothing in the sociotechnical quadrille that prevented them from switching back again if they considered it beneficial. However, and according to the logic of the quadrille, it was absolutely out of the question that they could appear to occupy the same position at the same time.

It currently appears that consensus has been reached, at least in some places, as the municipalities of Oskarshamn and Östhammar have decided to accept a final repository for nuclear waste within their boundaries (Elam and Sundqvist, 2007). Once SKB had come to an agreement with these two municipalities, it was hard for the national environmental movement to object to these municipal decisions on democratic grounds. Nevertheless, this does not imply technopolitical closure regarding nuclear waste management. On the contrary, as we will demonstrate in the following section, the divide between the antinuclear movement and the nuclear energy industry remains. The anti-nuclear movement's intention was clearly to cast doubt on the coastal sites, Oskarshamn and Östhammar. Thus, even SKB's opponents reconfigured their positions, by adopting scientific arguments regarding geology and hydrology.

\subsection{From political-1 to political-4}

The previous discussion of the shift in the technopolitical balance between confined research and concerned groups as articulated in the public debate from 1950 to the early twenty-first century indicates a radical deconstruction of nuclear waste management and the coconstruction of the implicated actors, enforced by the anti-nuclear movement and research in the wild. From total absence from the debate, concerned environmental and anti-nuclear 
groups in Sweden succeeded initially in deconstructing the actions and efforts of the confined nuclear power industry. They also succeeded in turning the nuclear waste management issue from a purely scientific and technical issue into an open technopolitical issue involving not only the expertise and authority of confined scientific actors, but also the knowledge produced by research in the wild (from political-1 to political-4). Concerned groups managed, in a way, to become co-constructors of radioactive waste management by challenging scientific investigations, measurements, and assessments and by counterproposing alternative methods. This shift was also to transform their epistemic status. Their involvement and entrenchment in the controversy mirrored their efforts to have their knowledge production recognized, which also legitimized their existence (cf. Callon et al., 2009, p. 105). In the following, we will analyze how concerned groups have become key actors in resolving the nuclear waste management issue over the last decade. We will also demonstrate how confined research, research in the wild, and their mutual antagonism helped reconstruct technoscientific knowledge and the KBS project, making radioactive waste into a political-6 issue.

\section{The environmental movement's efforts to reconstruct the final storage of spent nuclear fuel}

The fact that SKB had managed in 2002 to persuade two Swedish municipalities to accommodate a final repository for spent nuclear fuel implied a concrete consequence for the anti-nuclear movement: they could no longer question the democratic and dialogic grounds of KBS-3 implementation. When the company and the municipalities' elected representatives came to an agreement, it was impossible for the Swedish anti-nuclear movement to denounce the cooperation as democratically illegitimate. This reconfiguration produced extraordinary results. The quadrille was on and the concerned parties were to reassess their steps. An immediate result of the agreement between SKB and the municipalities of Oskarshamn and Östhammar was that the public debate concerning spent nuclear fuel was considerably toned down. As demonstrated, several environmental and anti-nuclear groups articulated the results of their research in the wild in the public debate on nuclear waste management, strongly challenging technoscientific practices and proposals of the nuclear power industry (e.g., the KBS-3 project). However, the public debate that, from the late 1960s to the early twenty-first century, had democratized the issue of radioactive waste storage by opening the citadel of technoscience to various concerned groups was to be replaced by another form of technopolitical strategy, mainly expressed in the work and research of the environmental movement. Such research was no longer "in the wild," but instead was based on purely technoscientific practices and principles.

\subsection{Concerned groups in new roles}

Indeed, the environmental movement had developed a new strategy by the end of 2004, and at the beginning of 2005, resistance to KBS-3 entered a new phase. Two new non-profit, nongovernmental organizations began operations: Miljöorganisationernas kärnavfallsgranskning (MKG; the Swedish NGO Office for Nuclear Waste Review) and Miljörörelsens kärnavfallssekretariat (MILKAS; the Swedish Environmental Movement's Nuclear Waste Secretariat). The first organization, MKG, consisted of the Swedish Society for Nature Conservation, Fältbiologerna (Field Biologists), and several local resistance groups in the regions that were candidates for hosting final repositories. The second 
organization, MILKAS, was founded by the national anti-nuclear group Folkkampanjen mot kärnkraft-kärnvapen (FMKK; the Swedish Anti-nuclear Movement) and Miljöförbundet Jordens Vänner (MJV; Friends of the Earth, Sweden). Both MKG and MILKAS are financed by the state Nuclear Waste Fund, a governmental authority that receives and manages the fees paid by the nuclear power companies and owners of other nuclear facilities in Sweden for developing safe methods for storing nuclear waste (MKG, 2004). According to a law enacted in 2003, environmental organizations were entitled to economic support from this fund, despite SKB opposition (MKG, 2004). Thereby, the role of the critics was officially sanctioned and institutionalized.

Despite what had been the case for environmental organizations before this century, MKG and MILKAS did not mainly seek to create negative publicity for KBS-3 through mass media and information campaigns. On the contrary, MKG and MILKAS aimed to persuade state authorities, through strictly scientific reports, letters, and investigations, that KBS-3 constituted an unjustifiable project based on shaky scientific grounds. Concerned scientists, among them nuclear engineers and geologists who had leading roles in both organizations, claimed to be able to reveal and scientifically analyze the shortcomings of KBS-3. MKG and MILKAS conducted their own scientific investigations of geological conditions, invited foreign scientific experts to workshops, and continuously cited the latest scientific results concerning groundwater flows, corrosion, radiation, and earthquakes during the ice age (Mörner 2009a; MKG 2008a; MILKAS 2007; Åhäll 2006; MKG 2005a; MKG 2005b). They maintained that their criticism of KBS-3 found strong support in refereed scientific papers published in peer-reviewed journals. In contrast, SKB's scientific reports were internally published and not subject to independent scientific scrutiny. In other words, MKG and MILKAS claimed to be maintaining a more scientific profile than were their SKB-employed colleagues. The research conducted by MKG and MILKAS was highly sophisticated scientific work; in addition, they sought support in scientific reports and scientifically reviewed specialist articles that they made available on their websites (MKG 2009a; MKG 2009b; MKG 2008c; MKG 2007a). These articles were essentially incomprehensible to anyone other than researchers familiar with fields such as geology, physics, and chemistry.

This research material was not posted for the sake of the public, but to acquire as much scientific credibility as possible in promoting their viewpoints. They now exploited the natural sciences' monopoly on truth, in the same way as SKB had done since the mid 1970s, but maintained that their use was undistorted by conflicting interests, in contrast to what the history of SKB bore witness to. MKG and MILKAS had abandoned their reluctance to engage indisputable scientific facts and instead enlisted them as allies by directing them against SKB's scientific reports ("polluted by financial profit interests"). Suddenly, the environmental organizations had become eager advocates of pure, undistorted science that could serve the common good. This time, it was not journalists, activists, or local residents who would unmask KBS-3, but scientists producing articles in refereed journals of high quality and credibility.

\subsection{Getting inside and reconstructing alternative solutions}

Since 2005, both environmental organizations have participated in meetings with municipalities, initiated debates with state authorities, participated in SKB's information meetings for concerned parties, and joined in workshops arranged by responsible governmental ministries. MKG and MILKAS were clearly no longer pariahs in seeking a resolution to the radioactive waste storage problem. Their aim was to become an obligatory 
passage point ${ }^{4}$ in nuclear waste management, and they sought to accomplish this by establishing themselves in the decision-making processes by "constructing" an alternative final repository concept and by continuously and directly addressing the government through letters, writings, investigations, suggestions, and the like (Mörner 2009a; Mörner 2009b; Hulthén et al 2010; MKG 2008a; MKG 2008b; MKG 2008d; MKG 2006a). Their criticism of KBS-3 focused on their allegation that it was impossible to keep spent nuclear fuel separate from the biosphere for over 100,000 years, something that the KBS-3 project considered necessary. MKG had several reasons for making this claim. MKG emphasized that the copper encasements would corrode even in oxygen-free water, as scientists at the Royal Institute of Technology in Stockholm had proved (MKG, 2007a). When corrosion occurred, contaminated groundwater would eventually reach the earth's surface. The fact that SKB had situated the final repository in two potential coastal sites, with municipal support, unmasked an emergency plan for a potential environmental disaster. In inland Sweden there were geological formations where groundwater flows were considerably slower. According to MKG and MILKAS, if a repository were, against all reason, constructed following the KBS-3 concept, it ought to be located in an inland region with slow groundwater flows. The sites that SKB had selected were therefore the worst available. The anti-nuclear movement's new strategy was based solely on discussing technical and scientific matters in the same way as SKB had for decades. In other words, at a time when agreement had been reached between SKB and two municipalities (a political decision), concerned groups and researchers in the wild aimed to reconstruct better technological alternatives instead of merely deconstructing existing ones. What alternatives for handling spent nuclear fuel did MKG and MILKAS advocate? Answering this question also involves discussing why the environmental movement split into two main organizations regarding the issue in the first decade of the twenty-first century.

\subsection{Deep drill holes and trust in natural barriers}

MKG, which received strong support from nuclear engineers at Chalmers Institute of Technology and from the Swedish Society for Nature Conservation, chose not to explicitly question nuclear power as an energy source, but instead to focus entirely on what method was most suitable for the final disposal of spent nuclear fuel (MKG, 2008a; Swahn, 2008). In line with SKB, MKG sought a technological solution. Although MKG claimed to be open to several disposal methods, it concentrated all its efforts on promoting a method for the final storage of spent nuclear fuel in 3-5-km-deep drill holes in bedrock (MKG 2008a; KASAM 2007; MKG 2007b; Lihnell Järnhester et al 2006; MKG 2006b; MKG 2006c; MKG 2006d). Accordingly, MKG financed an investigation of the potential to apply this method in Sweden, conducted by a geology professor, Karl-Inge Åhäll, who had been involved in nuclear waste issues for several decades. Åhäll argued that the method was promising and that the necessary technology seemed to be within reach, although some problems remained to be solved (e.g., how the encasements should be placed in their final destinations). Åhäll and MKG were optimistic about the approach because the encasements would be stored at a depth at which the groundwater was stratified by density and a saltwater barrier prevented

\footnotetext{
${ }^{4}$ An obligatory passage point constitutes a control station within a technoscientific dispute that must be passed in order for specific actors to accomplish their interests (Callon 1986, p. 205; see also Galis 2006, p. 27).
} 
radioactive substances from reaching the earth's surface, even if the encasements leaked (Åhäll, 2006). In other words, MKG's concept rested on the theory that one natural barrier could guarantee safety rather than several artificial ones.

MKG's support of deep underground storage of radioactive waste constituted somewhat of a paradox. MKG represented a significant part of the environmental movement that had previously opposed all underground storage of nuclear waste material and had accused SKB of putting its trust in a project (i.e., KBS-3) that relied on an unforeseeable future. This organization now advocated a concept that anticipated storage of spent nuclear fuel in tentimes-deeper bedrock and presupposed complete trust in the ability to predict the stability of nature for what comes close to eternity. The reconstructed underground storage of spent nuclear fuel that MKG supported also presupposed complete trust in the ability of science, above all geology and hydrology, to control nature comprehensively and a strong belief in engineers' ability to find infallible technical solutions to "grand-scale" management problems. Accordingly, MKG's argumentation rested on a strictly positivist understanding of science, a view of nature as fundamentally stable, and a technocratic view of society; people's future health and welfare were entirely dependent on the expert knowledge of scientists and on the competence of future engineers. MKG was committed to science and technological optimism-what SKB had earlier been accused of by environmental organizations.

On the other hand, both MKG and MILKAS maintained that their proposal for final storage was considerably more scientifically and technologically sophisticated than KBS-3 ever had been. Among other things, nuclear transmutation was proposed as a potential future alternative in combination with final storage in deep drill holes. If transmutation made it possible to reduce the volume of nuclear waste, the number of deep drill holes would also be considerably reduced. At the same time as demand mounted to investigate the potential of the deep drill hole concept, MKG asserted that test drillings to locate the most suitable bedrock ought to be conducted for research purposes (MKG 2008a; Lihnell Järnhester et al 2006; MKG 2006c; MKG 2006D; MKG 2007B; KASAM 2007). Important fractions of the environmental movement that previously had opposed all test drilling became now its most passionate advocate (MKG 2008b). To convince the authorities that it was a progressive actor, MKG repeatedly underscored that KBS-3 was a "30-year-old concept" based on "oldfashioned" technology, thereby insinuating that SKB was unprepared to evaluate the potential of contemporary and future technology. On the contrary and according to MKG's critique, SKB wanted to implement a method in which it had invested 30 years of effort. From this point, it was the environmental organizations, not SKB, that became the strategically most prominent interpreters of the notion of perpetual cumulative progress (MKG 2006e; MKG 2006d). It was rather obvious that MKG had changed its attitude towards underground storage; this time they had learned their lesson well, and refrained from discussing political matters, confining themselves strictly to technological alternatives. From this point on, the anti-nuclear movement in general made technopolitics using "purely" scientific means, while SKB made technopolitics using "purely" political instruments (cf. Anshelm and Galis, 2009, p. 278).

Spokespeople for SKB observed that, counter to the environmental organizations' past stance, they were now suddenly advocating an untested method that relied on the everlasting burial of nuclear waste material in the bedrock. SKB also claimed that the proposed method would require at least another 30 years of development, and that it entailed several uncertainties that would make it impossible to remove the radioactive 
material if something went wrong. SKB warned that the idea of leaving spent nuclear fuel in the bedrock and surrendering all control caused them unease. Although SKB did not seriously consider the concept of deep drill holes, responsible state authorities displayed significant interest in the idea, hosting special workshops in which the concept of deep drill holes was addressed. At the same time, the Swedish government maintained that SKB had to investigate alternative methods to KBS-3, especially the deep drill hole method. The government also criticized SKB for ignoring this demand in their R\&D reports (Miljödepartementet 2008; Miljödepartementet 2009; KASAM 2007). Since MKG had received this kind of response from state authorities and the government, their efforts may be perceived as somewhat successful. Moreover, MKG's research inspired the submission of a motion in parliament; picking up on MKG's rhetoric, the Swedish Green Party proposed a thorough investigation of the deep drill hole disposal method (Swedish Parliament, Bill 2006/2007:2406).

As already mentioned in this section, despite the fact that the environmental organizations participating in MKG represented 168,000 members the public debate in the media and via information awareness campaigns declined considerably in the first decade of the twentyfirst century. MKG had learned its lesson and was now fighting KBS-3 using the nuclear energy industry's own arsenal. One consequence of this was that MKG, like SKB, kept the question of whether or not nuclear power was a justifiable energy source separate from that of how spent nuclear fuel should be handled, a separation that had formerly been completely rejected by the environmental organizations. This implied, somewhat ironically, that MKG and its members - who had previously opposed nuclear power in general-were seeking to solve the most severe safety problem related to nuclear power production: reconstructing a promising method for underground storage, if suitable geological formations could be located (which MKG implied was possible). At least hypothetically, this meant that MKG could have removed a large obstacle to continued nuclear power production, permitting a new generation of nuclear reactors to be launched. An important fraction of the environmental movement was actively involved in solving the problem of the final storage of spent nuclear fuel, unintentionally to the benefit of the nuclear energy industry, even though SKB declared it was capable of developing its own solutions.

\subsection{Dry rock deposit and resistance to underground storage}

This constitutes one reason why the anti-nuclear movement is divided into MKG and MILKAS. In sharp contrast to MKG, MILKAS maintained that taking a stand for or against nuclear power as an energy source and working for the safe storage of spent nuclear fuel were two issues that should never be separated. To construct a solution for final storage, as MKG had, was unjustifiable for MILKAS. MILKAS also shared MKG's trust in science and employed scientific publications and experts as strong voices opposing KBS-3. It maintained, however, the early anti-nuclear movement's conviction that nuclear waste should not be stored underground in a final storage repository inaccessible to humans (Hulthén et al., 2010). The reasons for this position were the same geological and tectonic objections that MILKAS had raised against KBS-3. MILKAS underlined that geology was not a science that could foresee the future, and that nobody could reliably predict what could happen in an underground storage repository when earthquakes occurred, giving rise to fissures and faults, during any ice ages that might occur over the more than 100,000 years the spent nuclear fuel would remain deadly to almost all forms of life (Ahlin and Dörvaldt, 2007; KASAM 2007). Geologist Nils-Axel Mörner, who supported MILKAS, claimed that his 
research had proved that it was irresponsible to keep nuclear waste in the bedrock and that the notion of a final repository was a theoretical construct unsupported by geology. Accordingly, MILKAS opposed every idea for a final storage repository and questioned as unrealistic MKG's and SKB's objective of relieving future generations of the burden of radioactive fuel by permanently depositing it underground. The idea of a final storage in bedrock was perceived as insane. In contrast, the organization advocated storing nuclear waste to be accessible to future generations in what were called "dry rock deposits" (Hulthén et al 2010; Mörner 2009a; Mörner 2008; MILKAS 2007).

In this method, nuclear waste should be stored in carefully sealed deposits above the groundwater in rock formations that are continuously self-drained. The idea is that spent nuclear fuel should be conveyed transparently and responsibly via an open process, not simply dumped into a mutable and unpredictable nature. MILKAS justified its approach by invoking the potential of future technology, declaring that future generations would probably develop technological methods superior to KBS-3. Accordingly, it was important not to deprive future generations of their options. For example, MILKAS emphasized that nuclear transmutation and other future technologies might make it possible to neutralize or reduce the volume of spent nuclear fuel. According to MILKAS, simply dumping radioactive waste inaccessibly into the bedrock, as SKB and MKG advocated on the basis of strictly limited knowledge, would be an irreparable mistake. Correspondingly, MILKAS argued that all production of nuclear waste material must immediately stop, so as not to aggravate future problems of nuclear waste management (Mörner 2009a; Hulthén et al 2010; Ahlin and Dörvaldt 2007; KASAM 2007).

\subsection{The redistribution of epistemic status and the strengthening of technoscience}

The analysis of the efforts of MKG and MILKAS in the first decade of the twenty-first century has demonstrated that a former social protest group with limited technoscientific competence can transform itself into a significant group of scientific knowledge carriers and sophisticated technology producers. In many respects, the opposing sides have switched positions, bringing SKB closer to society (via communication with municipalities) while MKG and MILKAS became secluded in erudite research isolated from the public. In the case of MKG, this has led to a distancing from the social and ideological interests they were initially representing, i.e., struggling against nuclear power in general and condemning all underground storage of radioactive waste. When something becomes a technopolitical-6 issue, the involvement of concerned groups with technoscience entails the risk that these groups may abandon their ideological origins and slide into an introverted relationship with technoscientific practice. In the studied case, there has been a reversal and an absolute redistribution of epistemic status that strengthens the confinement of technoscience. The efforts of MKG and MILKAS to become legitimate and influential participants in the nuclear waste controversy by attempting to make their agendas, methods, and interests scientifically credible reminds us in STS that we have only been following one-half of the quadrille, that is, the deconstruction and, in the best case, the coconstruction of technoscientific controversies. We have been following scientists and technologists, scientific theories and technological artifacts (i.e., political-1, -2 , and -3 issues), and we have normatively advocated the recognition and participation of concerned groups in the technopolitical arena. What we have neglected, apart from analyzing what "politics by other means" stands for, is investigating the impact of technopolitics on the identity and practice of groups concerned by it. 
In this paper and in our empirical case, we have attempted to analyze the issues technopolitics addresses and, in turn, how these issues shape technopolitics (cf. Latour, 2007, p. 819). Over a period of fifty years, the Swedish environmental and anti-nuclear movements were not only engaged with but also exposed to the technopolitics of nuclear waste management. Such engagement challenged the perception of nuclear waste management as a purely technoscientific matter based on indisputable scientific facts (cf. Callon et al., 2009, p. 16), making it a technopolitical issue that was recomposed and reconstructed by the conflicts, negotiations, and research of diverse groups of legitimized experts, laypeople, ordinary citizens, and researchers in the wild. This had a very important effect on the identity and epistemic status of the environmental movement. On one hand, we can detect the detachment of MKG from its initial standpoint, namely, opposing nuclear power. On the other hand, both MKG and MILKAS, by interacting with and including numerous scientists in their organizations, shifted both their profiles and lines of argumentation, making them more science based and abandoning earlier activist tactics.

It is important to stress, however, that MKG and MILKAS never became technocratic. They kept their democratic organization structures, stayed close to participatory ideals, and appeared as activist groups that adopted the scientific means they needed to profoundly criticize and challenge the KBS-3 concept. At the same time, they reconstructed and advocated alternative solutions for storing spent nuclear fuel. In other words, they made politics using scientific means. In 2002, when SKB persuaded two municipalities to declare their willingness to host a final repository for spent radioactive waste, the anti-nuclear movement lost the fight over democratic legitimacy (political-4) to SKB. If nuclear energy opponents still hoped to block KBS-3 (which they did), they had to resume the fight on technoscientific grounds (political-6), since this was where the issue could be reopened for thorough scrutiny and new negotiations.

\section{Conclusion: Dancing the quadrille}

We have treated the management of spent nuclear fuel as a sociotechnical quadrille: four involved couples representing various social, ideological, and technoscientific interests (i.e., concerned groups, concerned scientists, professional politicians, and the nuclear power industry) waver between science, policy-making, and activism, pressed by the urgency of the accumulating spent nuclear fuel. This sociotechnical quadrille implies that, while scientists and technicians sought to display awareness of social norms (both governmental and non-governmental), concerned groups sought to bolster their scientific credibility to advance their engagement and proposals. Dancing the quadrille has promoted the development of one of the most advanced methods for the final storage of spent nuclear fuel in the world, the KBS-3 concept. The involvement of concerned groups, such as the antinuclear and environmental movements and their advocates (e.g., journalists and academics), as well as the work of the nuclear energy industry, authorities, and parliament have considerably shaped the KBS-3 project.

We have actually identified three major forms of knowledge/action enacted by concerned groups (see Table 2): criticizing/deconstruction, bridging the lay-expert epistemic divide/co-construction, and taking leadership in technological development/reconstruction (cf. Jasanoff, 1997). Over approximately four decades, concerned groups in Sweden have exerted considerable influence on the nuclear energy industry and on governments and state authorities, vehemently opposing state authorities and the national nuclear industry. 
This dynamic has been crucial for the development of a specific Swedish concept for the final underground storage of spent nuclear fuel. By extensively molding public opinionincluding vast media debate, extended written communication with state authorities, protest marches, and civil disobedience-concerned groups essentially forced the nuclear energy industry to invest in technological development and scientific research to refine the KBS-3 concept and resolve the shortcomings and uncertainties that critics did their best to detect. Likewise, state authorities and governments have been forced to pass new laws and increase the security oversight of technoscientific developments, as the scrutiny of KBS-3 by concerned groups has evoked reconsideration of the sufficiency of the technological and scientific knowledge base.

\begin{tabular}{|c|c|c|c|}
\hline $\begin{array}{l}\text { Meanings of } \\
\text { "political" }\end{array}$ & $\begin{array}{c}\text { What is at stake in each } \\
\text { meaning }\end{array}$ & Our case & Phases \\
\hline Political-1 & $\begin{array}{l}\text { New associations and } \\
\text { cosmograms }\end{array}$ & $\begin{array}{c}\text { Nuclear waste management as } \\
\text { a risk issue-new associations } \\
\text { between society, safety, and } \\
\text { energy production }\end{array}$ & \\
\hline Political-2 & $\begin{array}{l}\text { The public and its } \\
\text { problems }\end{array}$ & $\begin{array}{c}\text { The creation of critical, } \\
\text { concerned anti-nuclear groups }\end{array}$ & \multirow[b]{2}{*}{ De-construction } \\
\hline Political-3 & Sovereignty & $\begin{array}{c}\text { The Swedish state and nuclear } \\
\text { industry attempt to provide } \\
\text { guarantees regarding nuclear } \\
\text { waste management }\end{array}$ & \\
\hline Political-4 & Deliberative assemblies & $\begin{array}{l}\text { Concerned groups claim the } \\
\text { right to participate in } \\
\text { configuring nuclear waste } \\
\text { management }\end{array}$ & \multirow[t]{2}{*}{ Co-construction } \\
\hline (Political-5) & (Governmentality) & & \\
\hline Political-6 & $\begin{array}{l}\text { The re-confinement of } \\
\text { research in the wild }\end{array}$ & $\begin{array}{l}\text { Concerned groups produce } \\
\text { technoscientific solutions }\end{array}$ & Reconstruction \\
\hline
\end{tabular}

Table 2. Dancing the quadrille

In this way, concerned groups have played leading roles in configuring the technopolitics (political 2-4) of the Swedish concept for the final storage of spent nuclear fuel. By severely criticizing KBS-3 (de-construction), concerned groups initially dragged the nuclear energy industry and parliament into the dance by repeatedly revising, qualifying, and refining the proposals for constructing a repository for the final storage of spent nuclear fuel. By deconstructing the KBS-3 concept, these groups identified the points at which the proposed concept had to be improved. Concerned groups thus came to serve as a prominent critical voice in a process of technological development. The Swedish nuclear waste management case is interesting not only for its ambitious and technologically sophisticated project for disposing of spent nuclear fuel, but also for the critical and influential involvement of concerned groups. The anti-nuclear movement and its advocates did not limit themselves merely to democratizing decision-making regarding nuclear waste management through deliberative procedures (as was the case in several other major nuclear powers); they also 
claimed the right to participate in technological processes and developed, on their own, highly sophisticated scientific proposals.

Their engagement with technoscience unintentionally helped improve or co-construct KBS3 , which has become a reference concept for investments in sustainable nuclear power in the EU. As Jasanoff (1997) notes, there are hidden costs in relying on concerned groups, and some strategic choices can raise questions as to whose values and interests are represented by concerned groups (p. 587). In our case, concerned groups have increasingly come to perform a critical task that has been necessary for the progress of KBS-3, a task that neither the nuclear energy industry nor governmental authorities has succeeded in discharging, mainly due to profit interests or corporative alliances. Considered in this way, the development of the final storage of spent nuclear fuel stands out as a consequence of four decades of heated technopolitical struggle and not as an ex parte result of either the Swedish political culture, characterized by consensus-making and cooperation, or the achievements of purely technoscientific work. Concerned groups have, in sharp contrast to their intentions, been involved in co-constructing KBS-3.

The involvement of concerned groups in constructing a more secure storage method has exacted a significant cost: through this process, concerned groups have contributed greatly to increasing the political legitimacy of nuclear power. This occurred partly because the crucial efforts of concerned groups to make the KBS-3 a more secure concept enabled the right-wing government to repeal the moratorium on building new nuclear reactors, and partly because it enabled the EU to speak about sustainable nuclear energy. These ambiguous and unforeseeable consequences bear witness to the complex, important, and often paradoxical roles that concerned groups play in technopolitical controversiessomething that deserves more attention from the STS field. In any case, one conclusion that can be drawn from the analysis of the empirical case is that technopolitical controversies cannot be satisfactorily understood without a detailed analysis of the role and epistemic status of concerned groups.

Another conclusion of this study concerns how technopolitics have profoundly shaped and reshaped all concerned groups involved in constructing Swedish nuclear waste management. The nuclear energy industry was taken to task by individual whistleblowers in the early 1970s for starting reactors without having developed reliable methods for the long-term storage of spent nuclear fuel. Most of these critics were oppositional scientists, most of them physicists, who aimed to deconstruct the truth claims and claimed scientific hegemony of the nuclear power industry. However, in 1972 a broad and widespread antinuclear movement achieved a sensational breakthrough in the Swedish media. As a result, between 1973 and 1975, Dagens Nyheter, the largest daily Swedish newspaper, published more than 150 full-page debate articles questioning nuclear energy (Anshelm, 2000, pp. 119120). These articles were written by journalists, artists, engineers, physicists, researchers, politicians, and laypeople of all sorts. This "insurrection of subjugated knowledges" constituted loosely coupled activist networks and concerned groups that, supported by oppositional experts on nuclear physics, struggled against the nuclear power society and against the lack of reliable methods for managing the nuclear waste being produced. Their aim was to enlist public opinion on their side with the help of arguments, campaigns, public meetings, and protest marches.

During this process, the issue of spent nuclear fuel storage was transformed into a question of deliberative procedures (political-4). Purely technological and scientific questions were 
integrated into or even displaced by social and moral questions. What constituted a good society? What represented responsible behavior vis-à-vis coming generations? Who had the right to take huge risks on behalf of others? What were the moral and social consequences of making a whole society dependent on nuclear energy experts? Was the democratic deficit a morally acceptable price to pay for a potential rise in the material standard of living?

At the same time as the national anti-nuclear movement was gaining considerable influence among citizens and political parties (which resulted in a national referendum in 1980 on the future of nuclear power in Sweden), local resistance groups picked their own fights. In the 1980s, they opposed the search for a location for the final storage of spent nuclear fuel in their home districts. These groups engaged in civil disobedience and occupied workplaces to stop test drillings. Local resistance groups also consulted oppositional researchers, though they were primarily interested in protecting the local character of their struggle.

Early in the twenty-first century, the concerned groups' close and persistent scrutiny helped develop KBS-3 into one of the world's most elaborate and technologically reliable methods for storing spent nuclear fuel. This made it possible for two Swedish municipalities to declare that they were willing to host a repository. The great influence of concerned groups in co-constructing the repository forced them to change their own position in the dance yet again, to take a new step in the quadrille. For concerned groups to maintain their influence, they had to transform their (de-)(co-)constructing efforts into reconstructive ones. When the ideological struggle was lost, the fight over technological and scientific facts remained. After all, in times characterized by massive accumulations of information, concerned groups are expected to act as carriers/producers of technoscientific knowledge (Jasanoff, 1997, p. 589). Thus, an issue that since 1972 had been treated as social and moral was again transformed into a technoscientific one. The quadrille was turning again. There was no longer any room to lobby against or question the democratic legitimacy of KBS-3.

Instead, concerned groups, such as MKG and MILKAS, began to strongly oppose the scientific basis of KBS-3, adding another step to the quadrille. Moreover, they advocated alternative technological solutions for storing spent nuclear fuel. These concerned groups were dominated by engineers, experts, and scientists who, with the financial support of the Nuclear Waste Fund, organized seminars, invited international experts, ordered specific technoscientific investigations, produced scientific reports, discussed contemporary scientific articles on geology, hydrology, and corrosion, and critically assessed SKB's research and development reports and state investigations. They seldom courted public opinion through the media, but instead concentrated their pressure on state authorities, the government, municipalities, and the nuclear power industry. MKG and MILKAS acted as minor specialized sub-organizations, supported by major environmental groups. Their key task became finding alternative solutions to technologically complicated problems and demonstrating that more efficient technologies were available than that on which KBS-3 was based (political-6). Thereby, a necessary change in strategy changed the technopolitical configuration and completely reshaped how concerned groups exerted influence.

One question that emerges is how this change in strategy has influenced public support for the concerned groups. At the same time as the concerned groups gradually became more scientifically oriented and dependent on experts, public resistance to nuclear power and public fears regarding the long-term consequences of nuclear waste dramatically decreased. Did this shift signify the capitulation of subjugated knowledges and the domestication of research in the wild? Has the quadrille completely seduced the concerned groups? Which 
are the risks regarding the transformation of concerned groups from enactors of civil disobedience to "interactional or contributory experts" (cf. Collins and Evans, 2002, p. 254)? These are not easy questions and there are several obvious but also complicated answers. It is reasonable to assume that the transformation of concerned groups into core technoscientific actors, abetting the transformation of nuclear waste management into an absolute scientific and technological issue, has contributed to the re-confinement of technoscience and the disappearance of the nuclear waste issue from public debate. The public is not any longer invited to participate and make a difference. Once again, experts and interactional experts (including concerned groups such as MKG and MILKAS) are dealing with the public problems while the rest of the demos is left to passivity. Any necessary actions are to be undertaken by minor, specialized sub-organizations, reemphasizing the technopolitical democratic deficit. Whether this development is unavoidable or even, in some respects, desirable is hard to tell. However, it provides an excellent example of how concerned groups are shaped by technopolitics and a strong argument for conducting more in-depth studies of the phenomenon within the realm of social sciences.

The present case reminds us that the sociotechnical quadrille is all about balance. Technopolitical controversies contribute to the shifting of epistemic status, but this does not mean that all parties to a controversy will maintain their epistemic autonomy. In our interpretation, political-6 should refer to what Callon et al. (2009) call collaborative research that explores and redistributes epistemic identities (p. 265). Such research, however, should guarantee the equal and balanced participation of both the public and other interests in the configuration of technopolitics. This, in its turn, will guarantee the (re-)(co-)constructing of technoscience in progressive directions.

\section{References}

Ahlin E. and Dörvaldt, M. 2007. Inlägg från Miljöorganisationernas Kärnavfallssekretariat på KASAM:s seminarium om djupa borrhål. In MILKAS 2007-03-15, retrieved from http://www.nonuclear.se/sv//print/135

Ahlström, P-E. 1989. Ringa kunskaper hos allmänheten. Göteborgs-Posten, 29 December.

Alfvén, H. 1972. Fusionsenergi kan övervägas. Atomexperiment bör undvikas. Miljö och Framtid 1 (2), 6-7.

Alfvén, H. 1988. Alfvén manar till kamp. Sydsvenska Dagbladet, 30 August.

Anér, S. 1978. Säker avfallsförvaring är en lögn. Dagens Nyheter, 20 May.

Anshelm, J. (2000). Mellan frälsning och domedag. Om kärnkraftens politiska idéhistoria i Sverige 1945-1999. Symposion: Stockholm.

Anshelm, J. 2006. Bergsäkert eller våghalsigt? Frågan om kärnavfallets hantering i det offentliga samtalet i Sverige 1950-2002. Arkiv, Lund.

Anshelm, J. and Galis, V. 2009. The politics of high-level nuclear waste management in Sweden: confined research versus research in the wild. Environmental Policy and Governance, 19, 269-280.

Arpi, T. 1990. Är det här atomsoporna ska ligga? Metallarbetaren (5), 12-13.

Atomenergi AB 1957. Atomenergin och Sverige. Stockholm.

Avfallskedjan 2001. Kärnkraftsavfall. Avfallskedjan, Lerum. 
Barry, A. 2001. Political Machines: governing a technological society. The Athlone Press: New York.

Bildström, M. 1997. Kärnavfallet och demokratin. Uppsala Nya Tidning, 8 October.

Bjurström, S. 1986. Vi kan ta hand om kärnavfallet. Dagens Nyheter, 21 April.

Bjurström, S. 1988. Säkert slutförvar redan nu. Svenska Dagbladet, 17 March.

Bjurström, S. 1989. Kärnavfallet är riskfritt. Aftonbladet, 13 May.

Blomfeldt, J. 1976. Nej, ohygglig giftrisk i vattnet. Kvällsposten, 11 September.

Brynielsson, H. and Eklund, S., 1954. Atomreaktorer och atomenergi. Svenska Vattenkraftföreningens publikationer, Stockholm.

Callon, M. 1986. Some Elements of a Sociology of Translation: Domestication of the Scallops and the Fishermen of St. Brieuc Bay. In Power, action and belief: a new sociology of knowledge? Law, J. (ed.). Routledge: London.

Callon M. 2003. The increasing involvement of concerned groups in R\&D policies: what lessons for public powers? In Science and Innovation, Rethinking the Rationales for Funding and Governance. Geuna A., Salter A.J., and Steinmueller W.E (eds). Edward Elgar, Cheltenham UK.

Callon, M. and Rabeharisoa V. 2003. Research "in the wild" and the shaping of new social identities. Technology in Society 25(2), 193-204.

Callon, M. Barthe, Y. and Lascoumes, P. 2009. Acting in an Uncertain World: An Essay on Technical Democracy (Inside Technology Series). MIT Press, London.

Chilvers, J. 2005. Democratizing science in the UK: the case of radioactive waste management. In Science and Citizens: Globalization \& the Challenge of Engagement.

Melissa, L. Scoones, I. and Wynne, B. (eds.). Zed Books, London, UK.

Collins, H. and Evans, R. 2002. The Third Wave of Science Studies: Studies of Expertise and Experience. Social Studies of Science, 26(2), 235-96.

DeVries, G. 2007. What is Political in Sub-politics? How Aristotle Might Help STS. Social Studies of Science, 37(5), 781-809.

Edberg, R. 1988. Dödande sopor. Arbetet, 10 October.

Elam, M. and Sundqvist, G. 2007. Stakeholder Involvement in Swedish Nuclear Waste Management. SKI Report 2007:2. The Swedish Nuclear Power Inspectorate, Stockholm.

Elam, M. and Sundqvist, G. 2009. The Swedish KBS project: A Last Word in Nuclear Safety Prepares to Conquer the World? Journal of Risk Research, 12(7-8), 969-88.

Eriksson, B. et al. 1986. Dålig teater Birgitta Dahl. Dagens Nyheter, 7 April.

Falk, J. 1995. Kritik mot slutförvaring av kärnavfall. Dagens Nyheter, 27 May.

Foucault, M. 2003. Society must be defended: lectures at the Collége de France 1975-1976.

Bertani, M. and Fontana, A. (eds.). Picador: New York.

Funke, G. 1956. Sverige inför atomåldern. Bonniers, Stockholm.

Fälldin, T. 1976. Hotet mot vår framtid. Dagens Nyheter, 21 May.

Gahrton, P. 1988. Vill riksdagen verkligen ha avveckling? Göteborgs-Posten, 28 June.

Galis, V. 2006. From Shrieks to Technical Reports: technology, disability and political processes in building Athens Metro. Doctoral Thesis, Linköping University studies in arts and science, No. 374, Linköping University: Linköping.

Gillberg, B. 1970. Strålande framtid. Dagens Nyheter, 8 April.

Holmstrand, O. 1987. Vem tar ansvar för avfallet? Göteborgs-Posten, 24 December. 
Holmstrand, O. 1990. SKB saknar trovärdighet. Göteborgs-Posten, 7 January.

Holmstrand, O. et al. 2002. Sämsta platserna har valts. Dagens Nyheter, 4 January.

Holmström, L. 1984. Miljögruppen slår till. Expressen, 29 October.

Hulthén, C. Mörner, N.A, Törnqvist M. 2010. Yttrande över Miljökonsekvensbeskrivningmellanlagring, inkapsling och slutförvaring av använt kärnbränsle. In MILKAS, 2010. Djupa borrhål. Ett alternativ för slutförvaring av använt kärnbränsle? KASAM, Rapport 2007:6, retrieved from http://www.nonuclear.se/files/MilkasMKBsvar20100304MT_CH_NAM.pdf

Jasanoff, S. 1992. Science, Politics, and the Renegotiation of Expertise at EPA. Osiris, 2nd series, 7, 194-217.

Jasanoff, S. 1997. NGOs and the environment: from knowledge to action. Third World Quarterly, 18(3), 579-594.

Jasanoff, S. 2004. Science and Citizenship: a new synergy. Science and Public Policy, 31(2), 90-94.

Johansson, R. 1969. Plutoniumverk eller fortsatt liv. Göteborgs-Posten, 9 December.

Jugnell, D. 1970. Kärnkraften luftens räddare. Dagens Nyheter, 9 June.

Kantara, J. 2007. Skandinavische Verheltnisse. Frankfurter Allgemeine Zeitung, 8 April.

KASAM 2007. Djupa borrhål. Ett alternative för slutförvaring av använt kärnbränsle. KASAM Rapport 2007:6.

Kronick, J.C. 1984. Public Interest Group Participation in Congressional Hearings On Nuclear Power Development. In Citizen Participation in Science Policy. Petersen, J.C. (ed.). The University of Massachusetts Press, Amherst.

Larsson, K. 2000. SKB fick bakläxa. Dagens Nyheter, 18 February.

Latour, B. 2004. Why Has Critique Run out of Steam? From Matters of Fact to Matters of Concern. Critical Inquiry, 30(2), 225-248.

Latour, B. 2007. Turning Around Politics: A Note on Gerard de Vries' Paper. Social Studies of Science, 37(5), 811-820.

Lidskog, R. and Sundqvist, G. 2004. On the right track? Technology, geology and society in Swedish nuclear waste management. Journal of Risk Research 7 (2), 251-268.

Lihnell Järnhester, C. et al. 2006. Avfallet från kärnkraftverk kan få säker slutförvaring.

Dagens Nyheter, 1 June.

Lindeberg, S. 1976. Avslöja AKA-utredningen! Dagens Nyheter, 16 September.

Lindeberg, S. 1978. Förfalskningar och censur. Göteborgs-Posten, 8 October.

Lindell, B. 1970. Framtida strålning. Dagens Nyheter, 16 April.

Lindquist, P. 1997. Det klyvbara ämnet. Lund University.

Macfarlane, A. 2003. Underlying Yucca Mountain: the interplay of geology and policy in nuclear waste disposal. Social Studies of Science 33 (3), 783-807.

Mesman, J. 2007. Disturbing Observations as a basis for Collaborative Research. Science as Culture. Special Issue: Unpacking "Intervention" in STS. 16(3), 281-295.

Miljödepartementet 2008. Regeringsbeslut 38. M 2008/2772/MK. Miljödepartementet.

Miljödepartementet 2009. Kärnavfallsrådets yttrande över Svensk Kärnbränslehantering AB:s komplettering av Fud-programmet 2007. Miljödepartementet Yttrande. Dnr $61 / 08$.

MILKAS 2007. Miljöorganisationernas Kärnavfallssekretariats (MILKAS) remissutlåtande till SSI och SKI om SKB-rapporten SR-CAN. MILKAS 2007, retrieved from http://www.mkg.se/pdf/Milkas070820RemissutlatandeSR-CanMedBilaga.pdf 
MKG 2004. MKG bildat. MKG 2004-10-27, retrieved from http://www.mkg.se/mkg-bildat MKG 2005a. Seminarier med Clifton Voss i Göteborg och Stockholm. MKG 2005, retrieved from http:/ / www.mkg.se/seminarier-med-clifford-voss-i-goteborg-och-stockholm

MKG 2005b. Yttrande från Miljöorganisationernas Kärnavfallsgranskning (MKG) över SKB AB:s Fud-program 2004, MKG 2005, retrieved from http://www.mkg.se/sites/default/files/old/pdf/MKG_yttrande_FUD2004.pdf

MKG 2006a. Frågeställningar av vikt för den långsiktiga säkerheten av ett slutförvar av KBStyp under en istid. Brev till SSI och SKI. MKG 2006, retrieved from http://www.mkg.se/sites/default/files/old/pdf/MKG_till_SKI_SSI_om_sakerhet _under_en_istid.pdf

MKG 2006b. Miljöorganisationernas kärnavfallsgranskning ger sin syn på alternativ metod och plats för slutförvar av kärnavfall. MKG Rapport 1, 2006, retrieved from http://www.mkg.se/uploads/MKG_infoblad1_alternativ_web.pdf

MKG 2006c. MKG kommenterar kärnkraftindustrins kommentarer till debattartikeln på DN-debatt 1 Juni. MKG 2006, retrieved from http://www.mkg.se/mkg-pa-dndebatt-djupa-borrhal-miljomassigt-battre-for-slutforvar-av-karnkraftavfall

MKG 2006d. MKG kommenterar kärnkraftindustrins kommentarer till diskussionen om djupa borrhål i Agenda SVT, 8 oktober. MKG 2006, retrieved from http://www.mkg.se/mkg-kommenterar-karnkraftsindustrins-skbs-kommentarertill-diskussionen-om-djupa-borrhal-i-agenda-i

MKG 2006e. Kommentarer och frågor från Miljöorganisationernas kärnavfallsgranskning med anledning av kärnkraftsindustrins (kärnavfallsbolaget SKB AB:s) samrådsmöten om slutförvaring av använt kärnkraftsbränsle 2006-05-31 i Figeholm i Oskarshamn kommun och 2006-06-01 i Forsmark i Östhammars kommun. Brev till SKB. MKG 2006, retrieved from

http://www.mkg.se/sites/default/files/old/pdf/MKG_samradsfragor_060531_0 60601.pdf

MKG 2007a. Korrosion av koppar i syrefritt vatten och den långsiktiga säkerheten av ett slutförvar för använt kärnbränsle. MKG 2007, retrieved from http://www.mkg.se/index.php?id=news128

MKG 2007b. MKG publicerar PM från professor Karl-Inge Åhäll om djupa borrhål. MKG 2007, retrieved from http://www.mkg.se/mkg-publicerar-pm-fran-professor-karlinge-ahall-om-djupa-borrhal

MKG 2008a. Naturskyddsföreningens och MKG:s yttrande över industrins SKB:s, forskningsprogram Fud -07. MKG Rapport 3, 2008, retrieved from

http:/ / www.mkg.se/naturskyddsforeningens-och-mkgs-yttrande-over-fud-07som-rapport

MKG 2008b. Frågor från Miljöorganisationernas kärnavfallsgranskning, MKG, som ställdes vid mötet med Samråds- och MKG-grupp Forsmark i Östhammar, MKG 2008, retrieved from http://www.mkg.se/index.php?id=news163

MKG 2008c. Ny artikel om korrosion av koppar i närvaro av salt och sulfider. MKG 2008, retrieved from

http://www.mkg.se/sites/default/files/old/pdf/MKG_till_SKI_om_ny_artikel_o m_kopparkorrosion_080207.pdf 
MKG 2008d. Miljöorganisationernas kärnavfallsgranskning lämnar synpunkter inför regeringens beslut över kärnkraftsindustrins forskningsprogram för kärnavfall, Fud-07. Yttrande till regeringen. MKG 2008, retrieved from http://www.mkg.se/mkg-lamnar-synpunkter-infor-regeringens-beslut-overkarnkraftsindustrins-forskningsprogram-for-karna

MKG 2009a. Ny amerikansk rapport om den alternativa metoden djupa borrhåll. MKG 2009, retrieved from http://www.mkg.se/ny-amerikansk-rapport-om-den-alternativametoden-djupa-borrhal

MKG 2009b. Ny vetenskaplig artikel visar på risker med SKB:s slutförvar. MKG 2009, retrieved from http://www.mkg.se/ny-vetenskaplig-artikel-visar-pa-risker-medskbs-slutforvar

Moberg, E. 1976. Världen eller Forsmark? Dagens Nyheter, 24 October.

Mosesson, T. 1977. Kärnkraften - ett rörigt spel om miljarder. Kommunalarbetaren (12), 42-43.

Mörner, N-A. 1978. Avfall i urberget är vanvettigt. Dagens Nyheter, 1 June.

Mörner, N-A. 1979. Geologer stå upp för er vetenskap. Dagens Nyheter, 9 March.

Mörner, N-A. 1988. Kärnavfall i berg är otänkbart. Dagens Nyheter, 23 September.

Mörner, N-A. 2008. Platsval - Val? - Direktiv? Eller Vad? MILKAS 2008, retrieved from

http://www.nonuclear.se/files/morner20080604.pdf

Mörner, N-A. 2009a. Remissutlåtande över komplettering av Fud-program 2007. MILKAS 2009, retrieved from http://nonuclear.se/milkasfud2007.html\#morner

Mörner, N-A. 2009b. Öppet brev till SKB. MILKAS 2009, retrieved from http://nonuclear.se/sv/morner-oppett-brev-skb20090102.html

Nilsson, G. 1978. Vad kommer att hända med avfallet i berget? Skånska Dagbladet, 23 October.

Noresson, J-Å. 1985. Kynnet som försätter berg. Bokskogen, Göteborg.

Noresson, J-Å. 1986. Följ samvetets lag. KRUT (3), 28.

Ockwell, D. and Rydin, Y. 2006. Conflicting discourses of knowledge: Understanding the policy adoption of pro-burning knowledge claims in Cape York Peninsula, Australia. Environmental Politics, 15 (3), 379-398.

Papp, T. 1995. Avfall internationellt föredöme. Uppsala Tidning, 6 October.

Rainer, L. 1973. Hannes Alfvén “avrättar" regeringen. Sydsvenska Dagbladet, 20 June.

Ringsberg, C. 1984. Avveckla med förnuft. Arbetet, 9 March.

Rosenberg, G. 1977. Direktörernas kamp för kärnkraften. Aftonbladet, 11 April.

Rydell, R.J. 1984. Solving Political Problems of Nuclear Technology: The Role of Public Participation. In Citizen Participation in Science Policy. Petersen, J.C. (ed.). The University of Massachusetts Press, Amherst.

SKB, 1992. FUD-program 92. Kärnavfallets behandling och slutförvaring. SKB, Stockholm.

SOU, 1976: 30-31. Använt kärnbränsle och radioaktivt avfall.

Strauss, A. and Corbin, J. 1990. Basics of Qualitative Research: Grounded Theory Procedures and Techniques. Sage, London.

Strömkvist, S. 2006. Miljörörelsen tar strid om atomsoporna, Sydsvenska Dagbladet, 23 October.

Sundqvist, G. 2002. The Bedrock of Opinion: Science Technology and Society in the Sitting of High-Level Nuclear Waste. Kluwer Academic Publishers, Dordrecht.

Svedberg, T. 1955a. Några intryck från atomkonferensen i Géneve. Tiden 47 (8), 460. 
Swahn, J. 2008. Comment at the Swedish Society for Nature Conservation blog. 2008-12-10, 22:47. Retrieved from

http:/ / blogg.naturskyddsforeningen.se/mikael/2008/12/10/mark-lynas-anslutersig-till-minoritetens-perspektiv/\#comments

Swedish Parliament. Bill 2006/2007: 2406.

Thegerström, C. 1993. Kärnavfall i Storuman. Västerbottens-Kuriren, 17 February.

Thunell, J. Holmquist, C-E. and Wikdahl, C-E., 1977. Kärnkraftsexpertis nonchaleras. Sydsvenska Dagbladet, 26 April.

Westermark, T. 1952. Hur kan svensk industri utnyttja kärnvetenskapens resultat? Teknisk tidskrift 82, 602.

Westman, A-M. 1976. Kärnkraftens moral och ekonomi. Skånska Dagbladet, 4 November.

Woodhouse, E. Hess, D. Breyman, S. and Martin, B., 2002. Science Studies and Activism: Possibilities and Problems for Reconstructivist Agendas. Social Studies of Science 32(2), 297-319.

Åhäll, K. I. 1986. Rättsröta i kärnkraftens spår. Göteborgs-Posten, 15 December.

Åhäll, K. I. 2006. Slutförvaring av högaktivt kärnavfall i djupa borrhål. MKG Rapport 1, retrieved from

http://www.mkg.se/pdf/MKG_rapport1_djupa_borrhal_november2007.pdf 